УДК 373. 5. 016:53

\title{
ВИВЧЕННЯ ЯВИЩА РАДІОАКТИВНОСТІ Й ЗАКОНУ РАДІОАКТИВНОГО РОЗПАДУ В КУРСІ ФІЗИКИ В СЕРЕДНІХ НАВЧАЛЬНИХ ЗАКЛАДАХ
}

\author{
Віктор Надточій \\ завідувач кафедри фізики \\ доктор фізико-математичних наук, професор \\ ДВНЗ «Донбаський державний педагогічний університет», \\ м. Слов'янськ, Україна \\ ORCID ID 0000-0001-9890-171X \\ kafedrafiziki2018@gmail.com

\section{Олег Войнов} \\ старший учитель, спеціаліст вищої категорії, \\ учитель фізики астрономії та інформатики, \\ Миколаївський 33СО I-ІІІ ст. № 3 Миколаївської міської ради \\ м. Миколаївка, Україна \\ ORCID ID 0000-0002-1082-6565 \\ bytic2010@gmail.com

\section{Олександр Бєлошапка} \\ старший викладач кафедри фізики \\ ДВНЗ «Донбаський державний педагогічний університет», \\ м. Слов'янськ, Україна \\ ORCID ID 0000-0001-7448-3832 \\ beregslav2015@gmail.com
}

\begin{abstract}
Анотація. У цій статті розглянуто вивчення явища радіоактивності й закону радіоактивного розпаду в курсі фізики в середніх навчальних закладах. Автори пропонують матеріал із цієї теми, у якому використовуються оригінальні методичні прийоми, що допомагають осмисленню та усвідомленому застосуванні цього явища. Під час викладу матеріалу використовуються методи диференціального й інтегрального обчислення, знайомі учням із курсу математики. Цей матеріал можна використовувати під час проведення уроків, а також у процесі закріплення та розширення знань із цієї теми в учнів 11-их класів.

Ключові слова: радіоактивність; закон радіоактивного розпаду; постійна розпаду; час життя радіоактивного ізотопу; період напіврозпаду.

Постановка проблеми в загальному вигляді. Для дослідження структури й властивостей речовин велике значення має вивчення радіоактивного розпаду. Лише після відкриття радіоактивності стало можливим перетворення одних хімічних елементів в інші, синтез ядер елементів, що не існували на Землі. Вивчення радіоактивності значно розширило перспективи енергетики, призвело
\end{abstract}

Професіоналізм педагога: теоретичні й методичні аспекти. - Вип. 14 (Ч. 1). - Слов'янськ, 2021. 
до створення ядерної енергетики, ядерної зброї; радіоактивність знайшла застосування в сільському господарстві, медицині тощо. Водночас перед людством виникла ціла низка нових складних проблем, пов'язаних із запобіганням шкідливій дії випромінювання на живі організми. Для оцінки впливу випромінювання на живі організми необхідно добре розуміти закономірності процесів радіоактивного розпаду.

Аналіз останніх досліджень і публікацій. Методикою вивчення атомної та ядерної фізики в закладах загальної середньої освіти займалися П. Атаманчук, А. Бугайов, С. Величко, М. Мартинюк, Н. Садовий, І. Якименко та ін. У цілому вони визначили три варіанти методики навчання атомної та ядерної фізики: історичний: на основі радіоактивності й протонно-нейтронної будови ядра; квантовий - на основі квантових уявлень про будову і властивості речовини; інноваційний - у кінці XX - початку XXI ст. широке застосування отримали інноваційні, зокрема й інформаційно-комунікаційні технології (IКТ). Інформаційні технології дозволяють розробляти електронні підручники, демонстраційні та інтерактивні віртуальні експерименти, віртуальні лабораторні практикуми, практикуми-тренажери, комплекти комп’ютерних демонстрацій, автоматизовані системи контролю знань.

Проте в пропонованих у цей час підручниках і навчальних посібниках тему «Радіоактивність. Закон радіоактивного розпаду» викладено недостатньо повно. У деяких підручниках (Гончаренко, 2006; Засекіна і Засєкін, 2019 р.) висновок закону радіоактивного розпаду практично не надано, немає понять постійної розпаду, середнього часу життя радіоактивного ізотопу.

У підручнику «Фізика» (Бар'яхтар, 2019) закон радіоактивного розпаду виводиться в основній формі, немає зв'язку із середнім часом життя радіоактивного ізотопу. $\mathrm{y}$ зазначених підручниках практично не використовується математичний апарат, що зв'язує між собою основні величини, які характеризують розглянуті явища.

Формулювання цілей статті (постановка завдання). Але попри важливе значення фізики атома й атомного ядра, зміст цього розділу фізики в загальноосвітній школі не відображає сповна його зв'язку з іншими навчальними дисциплінами, а також практичного застосування отриманих знань. Програма 3 фізики для загальноосвітньої школи містить достатній обсяг знань, але значного вдосконалення потребує методика іiі викладу.

У зв'язку із цим метою роботи стало вдосконалення методики викладання атомної фізики в 11 класах загальноосвітньої школи й розробка уроків із цієї теми. 
Результати дослідження. Тема. Радіоактивність. Закон радіоактивного розпаду. Період напіврозпаду.

Мета. Розглянути явище природної радіоактивності й закон радіоактивного розпаду. Показати особливості застосування закону під час розв'язання задач.

Радіоактивність було відкрито в 1896 році французьким фізиком А. Беккерелем. Він займався дослідженням зв'язку люмінесценції та нещодавно відкритих рентгенівських променів.

А. Беккерелю спало на думку: чи не супроводжується різна люмінесценція рентгенівськими променями? Для перевірки своєї здогадки він взяв кілька з'єднань, зокрема й одну із солей урану, яка фосфоресцирує жовто-зеленим світлом. Освітивши іiі сонячним світлом, він загорнув сіль у чорний папір i поклав в темній шафі на фотопластинку, теж загорнуту в чорний папір. Через деякий час, проявивши пластинку, А. Беккерель дійсно побачив зображення частинки солі. Але люмінесцентне випромінювання не могло пройти крізь чорний папір, і лише рентгенівські промені могли в цих умовах засвітити платівку. Беккерель повторив досвід декілька разів і з однаковим успіхом.

24 лютого 1896 року в засіданні Французької академії наук він зробив повідомлення «Про випромінювання, що утворює фосфоресценцію». Але вже через кілька днів в інтерпретацію отриманих результатів довелося внести коригування. 26 і 27 лютого в лабораторії Беккереля було підготовлено наступний дослід із невеликими змінами, але через хмарну погоду він був відкладений. Не дочекавшись гарної погоди, 1 березня Беккерель проявив пластинку, на якій лежала уранова сіль, так і не опромінена сонячним світлом. Вона звичайно не фосфоресціювала, але відбиток на пластинці вийшов. Уже 2 березня Беккерель доповів про це відкриття на засіданні Паризької Академії наук, назвавши свою роботу «Про невидиму радіацію, вироблену фосфоресційованими тілами».

Згодом Беккерель випробував і інші сполуки, у тому числі мінерали урану (які не утворюють фосфоресценцію), а також металевий уран. Пластинка незмінно засвічувалася. Помістивши між сіллю та платівкою металевий хрестик, Беккерель отримав слабкі контури хрестика на пластинці. Тоді стало ясно, що відкрито нові промені, що проходять крізь непрозорі предмети, але не $є$ рентгенівськими.

Беккерель встановив, що інтенсивність випромінювання визначається тільки кількістю урану в препараті й абсолютно не залежить від того, у які

Професіоналізм педагога: теоретичні й методичні аспекти. - Вип. 14 (Ч. 1). - Слов’янськ, 2021. 
С В. НАДТОЧІЙ, О. ВОЙНОВ, О. БЕЛОШАПКА

Вивчення явища радіоактивності й закону радіоактивного розпаду в курсі фізики в середніх навчальних закладах

з’єднання він входить. Отже, ця властивість була притаманна не сполукам, а хімічному елементу - урану.

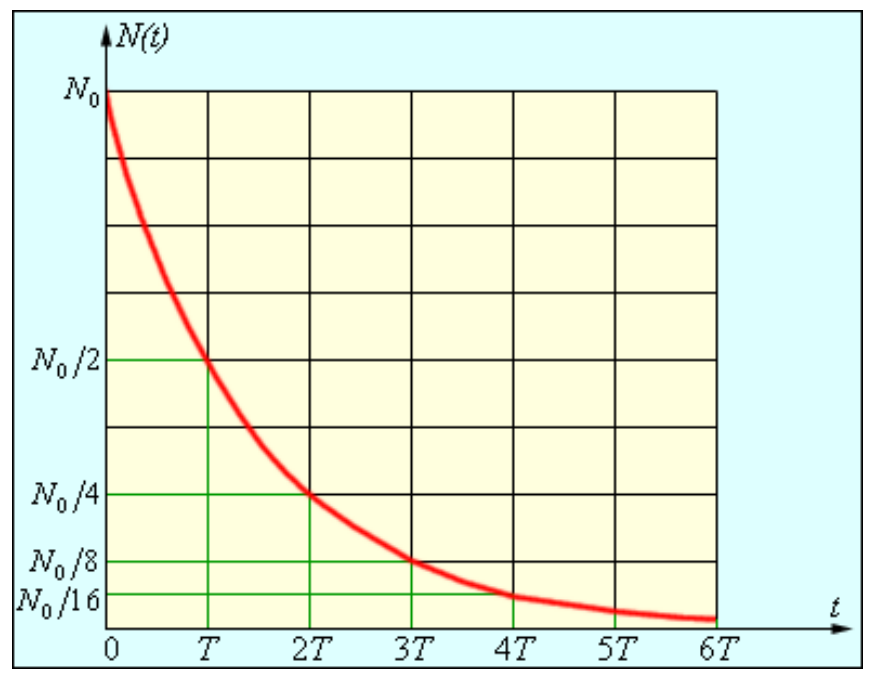

Рис. 1. Графік залежності N(t) кількості ядер, які не зазнали розпаду від часу

Закон радіоактивного розпаду - закон, відкритий Фредеріком Содді й Ернестом Резерфордом експериментальним шляхом і сформульований у 1903 році. Сучасне формулювання закону:

$\frac{d N}{d t}=-\lambda \cdot N \quad$ де $N-$ кількість атомів, $\lambda-$ показник розпаду радіоактивної речовини, що означає, що число розпадів $d N$ за інтервал часу $d t$ у довільному речовині пропорційно числу $N$ наявних у зразку радіоактивних атомів цього типу. Знак мінус вказує на спад числа радіоактивних ядер із часом

У наслідок численних експериментів iз різними радіоактивними речовинами Резерфорд встановив, що для кожної 3 них $є$ проміжок часу, протягом якого іï активність зменшується у 2 рази, тобто за цей час розпадається рівно половина радіоактивних атомів. Цей час називається періодом напіврозпаду Т. Наприклад, період напіврозпаду для урану ${ }_{92}^{238} U$ становить 4,5 млрд. років, для радію ${ }_{88}^{226} R a-1600$ років, для вуглецю ${ }_{6}^{14} C-5730$ років, для криптону ${ }_{36}^{94} \mathrm{Kr}-$ всього $1,4 \mathrm{c}$.

Отримаємо закон радіоактивного розпаду в найбільш простій формі та відзначимо основні особливості цього закону порівняно 3 іншими законами фізики.

На рисунку $N_{0}$ - число атомів (радіоактивних ядер), які не притерпіли розпаду в початковий момент часу $t_{0} ; N$ - число радіоактивних ядер у різні моменти часу $t$. За час $\Delta t=t-t_{0}$ число ядер $\Delta N=N_{0}-N$, які розпалися. 
Аналогічно через наступні проміжки часу $t_{2}, t_{3}, t_{4}, \ldots$ кількість ядер, які залишаться, «не зазнають розпаду» буде $N_{2}, N_{3}, N_{4}, \ldots$ відповідно.

\begin{tabular}{|c|c|c|c|c|c|}
\hline $\mathrm{n}$ & 0 & 1 & 2 & 3 & 4 \\
\hline $\mathrm{t}$ & 0 & $\mathrm{~T}$ & $2 \mathrm{~T}$ & $3 \mathrm{~T}$ & $4 \mathrm{~T}$ \\
\hline $\mathrm{N}$ & $N_{0}$ & $\frac{N_{0}}{2}$ & $\frac{N_{0}}{4}$ & $\frac{N_{0}}{8}$ & $\frac{N_{0}}{16}$ \\
\hline
\end{tabular}

$t_{0}=0$

$N=N_{0}-$ число ядер у початковий момент

часу, які не розпалися, тобто число радіоактивних ядер, готових до розпаду

$$
\begin{array}{ll}
t_{1}=T & N_{1}=\frac{N_{0}}{2} \\
t_{2}=2 T & N_{2}=\frac{N_{1}}{2}=\frac{N_{0}}{4}=\frac{N_{0}}{2^{2}} \\
t_{3}=3 T & N_{3}=\frac{N_{2}}{2}=\frac{N_{0}}{8}=\frac{N_{0}}{2^{3}} \\
t_{n}=n T & N_{n}=\frac{N_{n-1}}{2}=\frac{N_{0}}{2^{n}} \\
N=\frac{N_{0}}{2^{n}}=N_{0} \cdot 2^{-n} &
\end{array}
$$

Загальна формула для ядер, які не розпалися, має вигляд:

$$
t=n T \quad n=\frac{t}{T} \quad N=N_{0} 2^{-\frac{t}{T}}
$$

Кількість радіоактивних атомів у момент часу $\mathrm{t}$ після початку розпаду можна розрахувати за формулою $N=N_{0} 2^{-\frac{t}{T}}$.

Число розпалися атомів за час $\Delta t$ де $\Delta t=t-t_{0}=t-0=t$ можна розрахувати за формулою:

$$
\Delta N=N_{0}-N=N_{0}-N_{0} 2^{-\frac{t}{T}}=N_{0}\left(1-2^{-\frac{t}{T}}\right) .
$$

Зазначимо, що закон радіоактивного розпаду має низку особливостей порівняно з іншими законами експоненціального характеру:

a) цей закон має статистичний характер, тобто він справедливий для великої кількості частинок. Для малого числа атомів говорити про певну кількість їх розпаду і певному часу розпаду не має сенсу;

б) порівняно зі статистичними законами молекулярної фізики, радіоактивний розпад має випадковий характер, тому закон радіоактивного 
С В. НАДТОЧІЙ, О. ВОЙНОВ, О. БЕЛОШАПКА

Вивчення явища радіоактивності й закону радіоактивного розпаду в курсі фізики в середніх навчальних закладах

розпаду - це не просте узагальнення великої кількості розпадів, а найбільш імовірний результат поведінки великого числа радіоактивних атомів; частку окремих атомів передбачити дуже важко.

Розпад атома не залежить від його віку, тобто атоми «не старіють». Розпад будь-якого атомного ядра - це, так би мовити, не «смерть від старості», а «нещасливий випадок» у його житті. Для радіоактивних атомів немає поняття віку. Можна визначити лише середню тривалість (час) життя $\tau$.

Отримаємо закон радіоактивного розпаду в найбільш загальній формі $N=N_{0} e^{-\lambda t}$. Розглянемо основні особливості цієї форми запису закону радіоактивного розпаду.

$$
t_{0}=0 \quad N_{0}-\text { число ядер, що не зазнали розпаду в початковий }
$$
момент часу, тобто число радіоактивних ядер (атомів) у початковий момент часу $t_{0}=0$

$$
\begin{aligned}
& t \quad N-\text { число радіоактивних ядер (атомів) у момент часу } t \\
& \Delta t=t-t_{0} \quad \Delta N=N_{0}-N \text { - число ядер (атомів), які розпалися за } \\
& \text { проміжок часу } \Delta t \\
& \left.\begin{array}{l}
\Delta N \sim N \\
\Delta N \sim \Delta t
\end{array}\right\} \Rightarrow \Delta N \sim N \cdot \Delta t \Rightarrow \Delta N=-\lambda \cdot N \Delta t \\
& \lambda=\frac{-\Delta N}{N \cdot \Delta t}=\frac{-\Delta N / N}{\Delta t} \quad \lambda-\text { постійна радіоактивного розпаду. }
\end{aligned}
$$

Величина $\lambda$ називається постійною розпаду. Вона характеризує відносне зменшення числа ядер, що розпалися за одиницю часу.

Величина $\tau=1 / \lambda$ зворотна постійній розпаду називається середнім часом життя радіоактивного ізотопу. Величини $\lambda$ i $\tau$ не залежить від зовнішніх умов $\mathrm{i}$ визначаються лише властивостями атомного ядра.

$$
\left.\begin{array}{l}
\Delta N=-\lambda \cdot N \Delta t \\
\Delta N=-\lambda \cdot N \Delta t \\
d N=-\lambda \cdot N d t
\end{array}\right\} \Rightarrow \frac{d N}{N}=-\lambda d t
$$

Інтегруванням знайдемо відносну кількість ядер, які розпалися до моменту чacy $t$

$$
\int_{N_{0}}^{N} \frac{d N}{N}=\int_{0}^{t}-\lambda d t
$$

Відомо, що $\quad \int_{1}^{2} \frac{d x}{x}=\left.\ln x\right|_{1} ^{2}=\ln 2-\ln 1=\ln \frac{2}{1}=\ln 2$. Тоді 
Вивчення явища радіоактивності й закону радіоактивного розпаду в курсі фізики в середніх навчальних закладах
$\int_{N_{0}}^{N} \frac{d N}{N}=\int_{0}^{t}-\lambda d t$
$\left.\ln N\right|_{N_{0}} ^{N}=-\left.\lambda t\right|_{0} ^{t}$
$\ln N-\ln N_{0}=-\lambda t$
$\ln \frac{N}{N_{0}}=-\lambda t$
$e^{-\lambda t}=\frac{N}{N_{0}}$
$N=N_{0} e^{-\lambda t}$

Отримали другу, найбільш загальну форму закону радіоактивного розпаду. Визначимо середній час життя атомів за допомогою цього закону.

$$
\begin{array}{lll}
t=T & N=\frac{N_{0}}{2} \quad \text { Тому } \quad N=N_{0} e^{-\lambda t} \quad \frac{N_{0}}{2}=N_{0} e^{-\lambda T} \\
\frac{1}{2}=e^{-\lambda T} & \text { Тоді } \quad \ln \frac{1}{2}=\ln e^{-\lambda T} \quad \ln 2^{-1}=\ln e^{-\lambda T} \quad-\ln 2=-\lambda T \\
\ln 2=\lambda T & \text { Нарешті } \quad \lambda=\frac{\ln 2}{T} \quad \lambda=\frac{\ln 2}{T}=\frac{0,693}{T}
\end{array}
$$

Tому $\tau=\frac{1}{\lambda}=\frac{T}{\ln 2}=\frac{T}{0,693}=\frac{1}{0,693} \cdot T=1,44 T$

Остаточно отримуємо такий вираз

$$
\tau=1,44 T \quad \tau \sim T \quad T \uparrow \Rightarrow \tau \uparrow
$$

Перейдемо від показової форми закону радіоактивного розпаду до степеневої та отримаємо:

$$
N=N_{0} e^{-\lambda t}=N_{0} e^{-\frac{\ln 2}{T} t}=N_{0} e^{\ln 2 \cdot\left(-\frac{t}{T}\right)}=N_{0}\left(e^{\ln 2}\right)^{-\frac{t}{T}}=N_{0} 2^{-\frac{t}{T}} .
$$

Для закріплення матеріалу розглянемо розв'язок типових задач на застосування закону радіоактивного розпаду для закріплення матеріалу.

\section{Задача 1}

Зразок містить $\mathrm{m}=10$ г ізотопу плутонію ${ }^{239} \mathrm{Pu} 3$ періодом напіврозпаду $\mathrm{T}$ $=24400$ років. Визначити скільки ізотопів розпадається щомиті (швидкість розпаду)?

Дано

$$
m=10 г=10^{-2} \kappa 2
$$

ізотоп ${ }^{239} \mathrm{Pu}$

$$
\begin{aligned}
& M=239 \frac{2}{\text { моль }}=0,239 \frac{\kappa 2}{\text { моль }} \\
& T=24400 \text { лет }
\end{aligned}
$$

Знайти

$$
\frac{\Delta N}{\Delta t}-?
$$

Застосуємо формулу для розрахунку числа радіоактивних атомів у момент часу $\mathrm{t}$ після початку розпаду $N=N_{0} 2^{-\frac{t}{T}} \mathrm{i} \Delta N=-\lambda \cdot N \Delta t$ Tому $\frac{\Delta N}{\Delta t}=-\lambda \cdot N$ 
С В. НАДТОЧІЙ, О. ВОЙНОВ, О. БЕЛОШАПКА

Вивчення явища радіоактивності й закону радіоактивного розпаду в курсі фізики в середніх навчальних закладах

$$
\frac{\Delta N}{\Delta t}=-\frac{\ln 2}{T} \cdot N_{0} 2^{-\frac{t}{T}}=-\frac{N_{0} \ln 2}{T \cdot 2^{\frac{t}{T}}}=-\frac{N_{0} \ln 2}{T \cdot 1}=-\frac{N_{0} \ln 2}{T}
$$

Оскільки величина часу $\mathrm{t}=1 \mathrm{c}$ дуже мала порівняно 3 періодом напіврозпаду даного ізотопу $\mathrm{T}=24400$ років, то можна вважати, що $2^{\frac{t}{T}}=2^{0}=1$

$$
\begin{aligned}
& N_{0}=v N_{A}=\frac{m}{M} N_{A} \quad N_{0}=\frac{m}{M} N_{A}=\frac{0,01}{0,239} \cdot 6,02 \cdot 10^{23} \approx 2,5 \cdot 10^{22} \\
& T=24400 \pi \mathrm{rem}=24400 \cdot 365 \cdot 24 \cdot 3600 \approx 7,7 \cdot 10^{11} \mathrm{c} \\
& \frac{\Delta N}{\Delta t}=\frac{N_{0} \ln 2}{T}=\frac{2,5 \cdot 10^{22} \cdot 0,693}{7,7 \cdot 10^{11}} \approx 2,25 \cdot 10^{10} \frac{1}{\mathrm{c}}
\end{aligned}
$$

Задача 2

Скільки відсотків радіоактивних ядер кобальту залишиться через місяць, якщо період напіврозпаду дорівнює 71 дню?

дано

$t=1 \mathrm{мec}=30 \mathrm{cym}$ ізотоп ${ }^{60} \mathrm{Co}$

$T=71 \mathrm{cym}$

знайти

$\frac{N}{N_{0}}-?$
Застосуємо формулу для розрахунку числа радіоактивних атомів (ядер) у момент часу $\mathrm{t}$ після початку розпаду $N=N_{0} 2^{-\frac{t}{T}}$

$$
\begin{aligned}
& \frac{N}{N_{0}}=\frac{N_{0} 2^{-\frac{t}{T}}}{N_{0}}=2^{-\frac{t}{T}} \\
& \frac{N}{N_{0}}=2^{-\frac{t}{T}}=2^{-\frac{30}{71}} \approx 0,7461 \\
& \frac{N}{N_{0}} \approx 0,7461 \cdot 100 \% \approx 74,6 \%
\end{aligned}
$$

Задача 3

Яка частка радіоактивних ядер деякого елемента розпадається за час, що дорівнює половині періоду напіврозпаду?

дано

$t=\frac{T}{2}$

знайти

$\frac{\Delta N}{N_{0}}-?$
Застосуємо формулу для розрахунку числа радіоактивних атомів (ядер) у момент часу $\mathrm{t}$ після початку розпаду $N=N_{0} 2^{-\frac{t}{T}}$

$\frac{\Delta N}{N_{0}}=1-2^{-\frac{t}{T}}=1-2^{-\frac{T}{2 T}}=1-2^{2}=1-\frac{-}{\sqrt{2}}=1-0,7071 \approx 0,2929$

$\frac{\Delta N}{N_{0}}=\frac{N_{0}-N}{N_{0}}=1-\frac{N}{N_{0}}=1-\frac{N_{0} 2^{-\frac{t}{T}}}{N_{0}}=1-2^{-\frac{t}{T}}$

$\frac{\Delta N}{N_{0}} \approx 0,2929 \cdot 100 \% \approx 29,3 \%$

Домашне завдання 


\section{Висновки 3 дослідження і перспективи подальших розвідок у цьому} напрямі. В епоху високих технологій знання основ атомної та ядерної фізики необхідно будь-якій людині, яка вважає себе освіченою. Ці знання допоможуть у подальшому навчанні й успішній роботі в галузі не лише фізики, а й у галузі інформаційних технологій, у галузі хімії, екології, біології, медицини тощо.

Вивчення цих розділів фізики допоможе краще зрозуміти проблематику сучасної атомної енергетики, проблеми, пов'язані з впливом атомної енергетики на довкілля та здоров'я людини. Важливість теми, на нашу думку, полягає в тому, що атомна фізика викладається в 11 класі - на завершальному етапі вивчення фізики. Саме розділи фізики атома й атомного ядра формують в учнів цілісну картину світу й завершують формування світогляду учнів.

\section{СПИСОК ВИКОРИСТАНИХ ДЖЕРЕЛ}

1. Фізика і астрономія. Навчальні програми для 10-11 класів закладів загальної середньої освіти (рівень стандарту, профільний рівень) Авт. кол. під кер. Ляшенка О.І. Затверджено Міністерством освіти і науки України (наказ № 1539 від 24.11. 2017 р.)

2. Ландсберг, Г.С. (2016). Элементарный учебник физики. Т.3. Колебания волны. Оптика. Атомная и ядерная физика. Москва: Физматлит.

3. Тарасов, Л.В. (2010). Приобщение школьников к современной физике: Диалоги с учителем. Москва: Книжный дом «Либриком».

4. Иванов, Б.Н. (2002). Современная физика в шкколе. Москва: Лаборатория базовых знаний.

5. Делоне, Н.Б. (2006). Школе нужна современная физика. Физика в школе, №5, 3442.

6. Иванов, Б.Н. (2002). Современная физика в шкколе. Москва: Лаборатория базовых знаний.

7. Бар'яхтар, В.Г. (2019). Фізика (рівень стандарту, за навчальною програмою авторського колективу під керівництвом Локтева В. М.): підруч. для 11 кл. закл. загал, серед, освіти. Харків : Вид-во «Ранок».

8. Бар'яхтар, В.Г., Божинова, Ф.Я., Кірюхін, М.М. і Кірюхіна, О.О. (2011). Фізика. 11 клас. Академічний рівень. Профільний рівень: підруч. для загальноосвіт. навч. закл. Харків: Видавництво «Ранок».

9. Гончаренко, С.У. (2006). Физика. Учебник для 11 класса средней общеобразовательной школы. Киев: Освита.

10. Засєкіна, Т.М., Засєкін, Д.О. (2011). Фізика. 11 клас. Академічний рівень, профільний рівень. Підручник. Харків: Сиция.

\section{TEACHING THE PHENOMENON OF RADIOACTIVITY AND THE LAW OF RADIOACTIVE DECOMPOSITION IN THE COURSE OF PHYSICS IN SECONDARY EDUCATIONAL INSTITUTIONS}

\section{Viktor Nadtochii}

Doctor of Physics and Mathematical Sciences, Professor, Head of the Department of Physics, 
С В. НАДТОЧІЙ, О. ВОЙНОВ, О. БЄЛОШАПКА

Вивчення явища радіоактивності й закону радіоактивного розпаду в курсі фізики в середніх навчальних закладах

$$
\begin{gathered}
\text { SHEI “Donbas State Pedagogical University", } \\
\text { Sloviansk, Ukraine } \\
\text { ORCID ID 0000-0001-9890-171X } \\
\text { kafedrafiziki2018@gmail.com }
\end{gathered}
$$

\author{
Oleh Voinov \\ Teacher of Physics, Astronomy and Computer Studies \\ Mykolaivka Secondary Comprehensive Institution № 3 of Mykolaivka Town Council \\ Mykolaivka, Donetsk region, Ukraine \\ ORCID ID 0000-0002-1082-6565 \\ bytic2010@gmail.com
}

\title{
Oleksandr Bieloshapka
}

\author{
Senior Lecturer of the Department of Physics \\ SHEE "Donbas State Pedagogical University" \\ Sloviansk, Donetsk region, Ukraine \\ ORCID ID 0000-0001-7448-3832 \\ beregslav2015@gmail.com
}

\begin{abstract}
The article offers practical material on the study of the phenomenon of radioactivity and the law of radioactive decay in the physics course of institutions of general secondary education. Taking into account the recommendations of the Ministry of Education and Science of Ukraine, this material is included in the list of mandatory questions provided for consideration in the classroom in high school.

The substantive part of the material proposed by the authors on the topic is selected taking into account modern scientific achievements in the field under consideration, the methodological part takes into account modern approaches to the organization of the educational process in high school, using original methodological techniques that help the comprehension and subsequent conscious practical application of the studied material. The connection with mathematics as a calculating tool is fundamentally important in forming the basis for complex perception and conscious assimilation of the material. Therefore, in the proposed presentation of the material, the methods of differential and integral calculus are used, familiar to students from the course of algebra. The indicated integration, by means of physics as a general educational discipline, contributes to the formation of comprehensive practical knowledge on the application and processing of information in general, and also provides its contribution to the development of an educationally mobile personality, focused on further self-education and self-development, taking into account the dynamics of society and scientific progress.

The proposed material allows for variability of use in the educational process, taking into account full-time, distance and mixed forms of conducting classes. Consolidation and expansion of knowledge of $11^{\text {th }}$ grade students on this topic is provided through repeated repetition and complication with a small and affordable "step" of complexity. The proposed material allows for variability of use in the educational process, taking into account full-time, distance and mixed forms of conducting classes. Consolidation and expansion of knowledge of $11^{\text {th }}$ grade students on this topic is provided through repeated repetition and complication with a small and affordable "step" of complexity. The proposed material allows for variability of use in the educational process, taking into account full-time, distance and mixed forms of conducting classes. Consolidation and expansion of knowledge of $11^{\text {th }}$ grade students on this topic is provided through repeated repetition and complication with a small and affordable "step" of complexity.
\end{abstract}




\section{В. НАДТОЧІЙ, О. ВОЙНОВ, О. БСЛОШАПКА}

Вивчення явища радіоактивності й закону радіоактивного розпаду в курсі фізики
в середніх навчальних закладах

The need for this study and the formation of a lesson based on such a methodological approach is associated with the peculiarities of the presentation of "Physics of the atom and the atomic nucleus" in the physics course of educational institutions. The time interval of the study (the end of the academic year) and the obvious parsimony of a real experiment leave a negative imprint on the quality of assimilation of the spectrum of topics from this section.

In the era of high technologies, knowledge of the basics of atomic and nuclear physics is necessary for any person who considers himself educated. This knowledge will help in further training and successful work in the field of not only physics, but also in the field of information technology, in the field of chemistry, ecology, biology, medicine, etc.

It is also important to take into account that it is atomic and nuclear physics that are largely capable of demonstrating the speed of scientific progress and the depth of human cognition of matter, which is fundamentally important for the formation of a holistic picture of the world and worldview in the minds of students.

Key words: radioactivity; the law of radioactive drop; post-drop; time of life of radioactive isotope; period of radioactive drop.

\section{REFERENCES}

1. Physics and astronomy. Curricula for the $10^{\text {th }}-11^{\text {th }}$ grades of general secondary education institutions (standard level, profile level). Eds. Liashenko O.I. Approved by the Ministry of Education and Science of Ukraine (Order № 1539, 24.11.2017).

2. Landsberg, G.S. (2016). Elementary textbook of physics. Vol.3. Wave oscillations. Optics. Atomic and nuclear physics. Moscow: Fizmatlit.

3. Tarasov, L.V. (2010). Introducing schoolchildren to modern physics: Dialogues with the teacher. Moscow: Librikom Book House.

4. Ivanov, B.N. (2002). Modern physics at school. Moscow: Laboratory of basic knowledge.

5. Delone, N.B. (2006). The school needs modern physics. Physics in School, 5, 34-42.

6. Ivanov, B.N. (2002). Modern physics at school. Moscow: Laboratory of basic knowledge.

7. Baryakhtar, V.G. (2019). Physics (standard level, according to the curriculum of the author's team under the direction of V.M. Loktev): textbook. for the 11 grade. Kharkiv: Ranok Publishing House.

8. Baryakhtar, V.G., Bozhynova, F.Ya., Kiriukhin, M.M., \& Kiriukhina, O.O. (2011). Physics. Grade 11. Academic level. Profile level: textbook. Kharkiv: Ranok Publishing House.

9. Goncharenko, S.U. (2006). Physics. Textbook for the 11th grade of secondary school. Kiev: Education.

10. Zasiekina, T.M., Zasekin, D.O. (2011). Physics. Grade 11. Academic level, profile level. Textbook. Kharkiv: Sicia. 